\title{
The influence of urban form on car travel following residential relocation: a current and retrospective study in Scottish urban areas
}

\author{
Lee Woods ${ }^{\text {a }}$ \\ University of Portsmouth
}

\author{
Neil S. Ferguson ${ }^{b}$ \\ University of Strathclyde
}

\begin{abstract}
Spatial planning and policy continues to be used as a tool to bring about changes in travel behavior. Policy suggests that by creating particular urban forms, demand for travel by car can be reduced. This paper uses data collected in 2006 from 280 households in Glasgow and Edinburgh to analyze the relationships between urban form and vehicle miles driven, with an emphasis on those who had recently relocated. Population densities, housing type, distance to urban center, and measures of mix were collected for the current residential location and prior residence for those who had relocated in the previous three years. An ordinal regression model of change in urban form showed significant associations with reported change in miles driven, although the effect was small compared with the effects of socioeconomic factors and car ownership. While the results give some weight to intensification as a policy to bring about a reduction in average distance driven, there may be an increase in total distance driven in the intensified area with a corresponding increase in congestion. Whether such intensification can be enacted against a backdrop of preferences toward suburban, car-oriented living is contentious. As such, this study calls into question the use of planning policy as a means to reduce car use in Scottish cities.
\end{abstract}

\section{$1 \quad$ Introduction}

There has been a long-standing interest in the nature of the relationship between land use configuration and travel demand. The principal motivation is to evaluate the extent to which land use regulation can be used to bring about more sustainable patterns of travel behavior. As in many countries, regions, and cities around the world, land use planning policy in Scotland promotes intensification of the built environment in order to address problems of environmental and resource degradation (Williams 2004). Planning policy in Scotland (National Planning Framework 2004; Scottish Planning Policy 2010) is based on the premise that land use planning can be used to reduce the growth, or the level, of car traffic. This paper describes a study that aims to inform policymakers of the validity of this premise by providing fresh evidence of the causal relationship between urban form and the distance traveled by car in Scottish cities.

The continued use of land-use planning policies to influence travel behavior has led to an increasing level of research into the nature of the relationship. Since the early work by Newman and Kenworthy (1989), who found an association with petroleum consumption and city density for 33 cities across the world, most studies have focused on one or more urban areas within a particular region or country, although there are a small number of more recent transnational studies of travel behavior and urban form such as Timmermans et al. (2003) and Souche (2010). Most subsequent studies have focused on single cities or countries, addressing much of the criticism of the early work by Newman and Kenworthy for its lack of control for other factors that are likely to affect the travel behavior of residents from different national or regional contexts-including government policy, incomes, and costs of transport (Gordon and Richardson 1989). While some subsequent studies found no significant associations between urban form and travel behavior (e.g., Boarnet and Sarmiento 1998), the majority of subsequent research based in the United States found that "neo-traditional" attributes of mixed use and higher densities arranged around a grid street pattern were associated with less distance traveled by car or fewer trips made by car (Cervero and Kockelman 1997; Cervero 2002; Ewing et al. 2003; Khattak and Rodriguez 2005).

A similar pattern of findings has been reported in Europe, where "neo-traditional" attributes are more commonplace. Findings from studies of a range of urban forms also suggest that higher residential density, closer to an urban center, and more mixed land uses are associated with a lower demand for travel by car (Stead 2001; Dieleman et al. 2002; Snellen et al. 2002; Naess 2005).

However, association does not demonstrate causation between urban form and travel behavior (Handy et al. 2005). Longitudinal observations or experiments are particularly useful in demonstrating the time order of changes in urban form and changes in travel behavior. However, longitudinal studies are rare because of the timescales over which urban forms and travel behavior change and difficulties in controlling for other factors over such a period of time. From analysis of a longitudinal aggregate dataset of travel and urban form in Lon-

a lee.woods@port.ac.uk br.s.ferguson@strath.ac.uk 
don, Williams (1997) found that “...three London Boroughs which had been intensified over a ten year period showed no reductions in car use. Travel patterns were so complex, due to lifestyle shifts such as cross-London commuting for work, and increased journeys for leisure, that no relationship could be found." There are a small number of quasi-longitudinal studies in the U.S. and China (Cervero and Day 2008; Handy et al. 2005) that have utilized current and retrospective recalled data. Similarly, in the U.K., Aditjandra et al. (2012) analyzed the relationships between neighborhood design and travel behavior for 219 households in 10 neighborhoods in northeast England. The study found that changes in socio-demographic characteristics explained much of the changes in car ownership. Changes in urban form influenced small changes in travel behavior directly and also indirectly through change in car ownership.

While there is limited evidence as to how changes in urban form are associated with changes in travel behavior (Krizek 2003; Vandermissen et al. 2003; Aditjandra et al. 2012; Handy et al. 2005; Su 2010), such studies are rare and as such, no consistent body of evidence exists on those measures of urban form that are important in any particular national or regional context. Moreover, studies that have investigated travel related to specific activities do not consider that reductions in travel for one activity might be offset by increases for other activities (i.e., compensation) (Naess 2005). Although a body of evidence is emerging on the associations between urban form and travel behavior, fewer studies have determined how changing urban form relates to changes in travel behavior, which is often one aim of planning policy. As such there is little evidence as to whether changing urban form through planning policy will relate to the desired changes in travel behavior in any particular national or regional context.

Further doubts also surround the ability of planning policies to create such changes to urban form (Stead and Hoppenbrouwer 2004; Breheny 1997; Hull 2007; Senior et al. 2004). In this regard, Williams (1999) argues that, “...although the policies may have benefits in terms of sustainability, their effects may be so complex, and their potential to be implemented so riddled with problems, that they are unlikely to produce the planned outcomes."

This research was carried out as part of the wider CityForm research program that investigated links between urban form and several aspects of sustainability including travel behavior (Jenks and Jones 2010). The aim of the study reported in this paper was to examine the effect of a change in urban form arising from a residential relocation on car use. This is one of only a handful of studies to adopt a quasi-longitudinal design and is the first to be carried out in a Scottish context.
This design enabled an analysis of change in urban form and change in car use for all activities to be analyzed, thus providing new evidence as to whether changing urban forms can reduce car use and hence, the efficacy of Scottish planning policies.

\section{Research design}

The study utilized a current and retrospective recall survey of households in Glasgow and Edinburgh, with a focus on those who had moved home in the preceding three years. Information was collected on levels of car ownership and use and residential and employment locations, along with other sociodemographic data. Attitudinal data were excluded from this analysis, as respondents might not reliably recall attitudes held some time before the date of the survey (Wall and Williams 1970).

\section{Case study neighborhoods}

Glasgow and Edinburgh, which are Scotland's two largest cities, are situated approximately 65 kilometers apart in the most populated part of Scotland. Each city has a suburban rail network, extensive bus routes, and in the case of Glasgow, a small underground rail line. Within each city, three case study areas were selected: in Glasgow they were the Merchant City/Calton area, Pollokshields, and Darnley; in Edinburgh, they were Dalry, Restalrig, and Corstorphine. The areas were chosen to reflect the urban form typically found in the inner, middle, and outer areas of each city, respectively. Figure 1 shows the road network and location of each case study area within each city. 

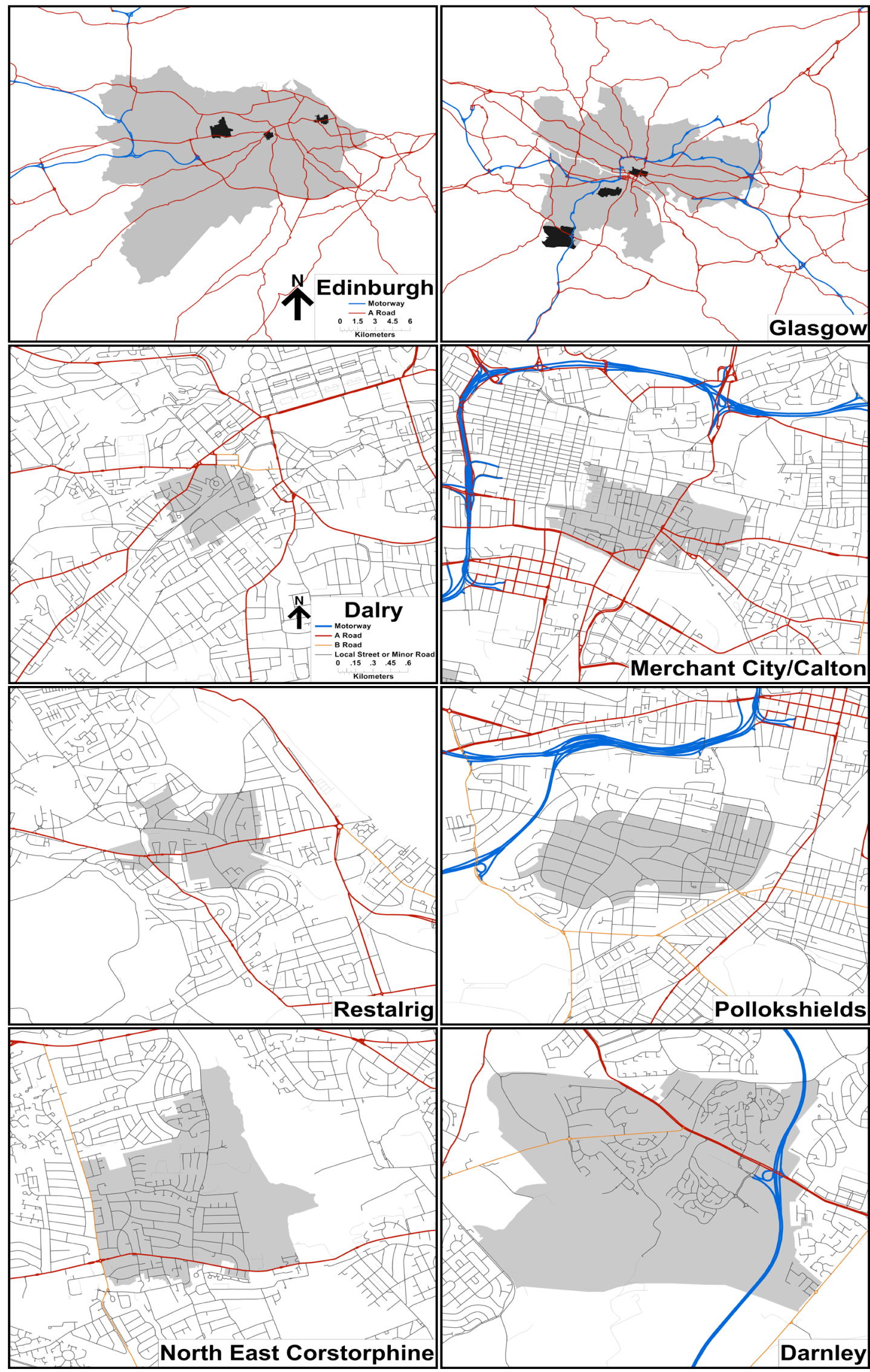

Figure 1: Case study areas in Edinburgh and Glasgow [@ 2013 Crown Copyright/database right]. 
Each area included at least 2,000 households, a mix of land uses, and households with a range of socioeconomic backgrounds. Indications of the built form and car ownership of the case study areas are provided in Table 1 . These areas represent a range of urban and suburban typologies found in Glasgow and Edinburgh (Frey et al. 2005).

\begin{tabular}{|l|r|r|r|r|r|r|}
\hline & \multicolumn{3}{|c|}{ Glasgow } & \multicolumn{3}{c|}{ Edinburgh } \\
\cline { 2 - 7 } & Inner & Middle & \multicolumn{1}{c|}{ Outer } & \multicolumn{1}{c|}{ Inner } & \multicolumn{1}{c|}{ Middle } & \multicolumn{1}{c|}{ Outer } \\
\hline & $\begin{array}{l}\text { Calton } \\
\text { shields }\end{array}$ & Darnley & Dalry & Restalrig & $\begin{array}{c}\text { Corstor- } \\
\text { phine }\end{array}$ \\
\hline Area (ha) & 3694 & 9863 & 6456 & 2958 & 4107 & 17227 \\
\hline $\begin{array}{l}\text { Gross density } \\
\text { (residents/ha) }\end{array}$ & 34.7 & 33.1 & 8.2 & 92.3 & 37.9 & 18.3 \\
\hline $\begin{array}{l}\% \text { of area covered } \\
\text { by residential } \\
\text { buildings }\end{array}$ & 14 & 14 & 2 & 14 & 14 & 10 \\
\hline $\begin{array}{l}\% \text { of area covered } \\
\text { by residential } \\
\text { gardens }\end{array}$ & 1 & 40 & 8 & 11 & 31 & 34 \\
\hline $\begin{array}{l}\% \text { of area covered } \\
\text { by green space }\end{array}$ & 29 & 16 & 77 & 24 & 24 & 38 \\
\hline $\begin{array}{l}\% \text { of residents } \\
\text { without access to } \\
\text { a car }\end{array}$ & 37 & 15 & 19 & 34 & 26 & 9 \\
\hline $\begin{array}{l}\text { Street layout } \\
\text { (classified by eye) }\end{array}$ & $\begin{array}{c}\text { Deformed } \\
\text { compact } \\
\text { grid }\end{array}$ & Grid & $\begin{array}{l}\text { Dispersed } \\
\text { cul-de-sacs }\end{array}$ & $\begin{array}{c}\text { Compact } \\
\text { grid and } \\
\text { cul-de-sac }\end{array}$ & Grid & Compact \\
grid
\end{tabular}

Table 1: Comparison of case study areas (Jenks and Jones 2010).

Three variables were selected to characterize urban form: (1) residential population density, (2) the ratio of employment to residential population, representing land use mix, and (3) the distance to the city center. Residential population and employment data were obtained from the 2001 census (General Register Office for Scotland 2001). The distance to the city center was taken as the Euclidian distance from the residence to the city center. If a respondent had relocated recently, then the urban form characteristics of his or her previous ward of residence were also collected and additionally, the size of the nearest urban area was recorded based on the eight categories described by Scottish Executive (2004), from "Large Urban Areas" (more than 125,000 people) to "Very Remote Rural" (less than 3,000 people and with a drive time of more than 60 minutes to a settlement of 10,000 or more). An additional category was created for those who had moved from London, while all those moving to the U.K. from overseas were excluded from the study. Although spatial dependency is recognized as an issue where samples are clustered (Bhat and Zhao 2002), it is important to recognize that the focus of this research is on the change in distance driven rather than current distance driven. While respondents were spatially clustered in six case study areas, their previous residential locations were not clustered. Hence, spatial dependence between observations was not considered to be a problem with this particular data set.

\section{$4 \quad$ Travel survey}

A survey was undertaken in the six neighborhoods, which provided information about respondents' travel behavior and available transport resources as well as household characteristics. The questionnaire was 14 pages long, included a four-day travel diary, and was conducted using a mail-out mail-back format.

The survey was carried out in June 2006. Respondents were asked a series of questions related to their current circumstance and their previous circumstances at the end of 2002, thus enabling any changes that had taken place in this three-and-a-half-year period to be recorded, as per Handy et al. (2005). This period was deemed to strike an appropriate balance between the need to identify a sufficiently large number of home-movers and the ability of respondents to provide reliable recalled data. Data were obtained from the Registers of Scotland for all property sales that had taken place from 2003 to 2006. All addresses highlighted as having been sold in the three-year period were selected for possible inclusion in the sample. Addresses that appeared commercial in nature or incomplete were removed. A further set of residential addresses obtained from the Ordnance Survey (2008) were added to this list. A total of 2,495 addresses were selected, of which approximately two-thirds were addresses for which a sale had taken place in the previous three years. In accordance with Dillman (2007), contact was first made with households using a prenotice letter that was timed to arrive approximately one week before receipt of the questionnaire. This letter introduced the household to the study and explained its purpose. A follow-up letter was sent to households that had not responded within a two-week period. A total of 452 letters were returned as "address unknown." In total, 281 completed questionnaires were returned, which represents a response rate of 13.7 percent. This was in line with expectations given the burden of completing the questionnaire, particularly the four-day travel diary, and is within the range achieved in similar studies such as the 11 percent response achieved by Kitamura et al. (1997) and 16 percent by Xing et al. (2010).

Respondents were asked to compare their current car use as a driver or passenger with their car use at the end of 2002. Permissible responses were (a) a lot less, (b) a little less, (c) about the same, (d) a little more, and (e) a lot more. Simi- 
larly, respondents were asked to provide details of their current household income and to compare this with their income at the end of 2002. For each respondent, the survey also collected details of current and previous (end of 2002) residential location, car availability, possession of driving license, employment status, workplace location and parking availability, and mode of transport used for commuting to work.

\section{$5 \quad$ Analysis}

To determine whether a statistically significant association between changes in urban form and in self-reported distance driven existed, and to control for the effects of socioeconomic variables, an ordinal regression model was developed. A negative-log-log link function was found to relate to the best model fit. Reported change in driving, measured on a Likert scale from "a lot less" to "a lot more," was entered as the dependent variable. Explanatory variables, as described in Tables 2 and 3, were entered into the model and refined using a backwards removal method. Missing data were excluded on a list-wise basis.

\begin{tabular}{|c|c|c|c|c|c|c|}
\hline Variable & Mean & Maximum & Median & Minimum & $\begin{array}{c}\text { Standard } \\
\text { Deviation }\end{array}$ & Count \\
\hline $\begin{array}{c}\text { Change in ward den- } \\
\text { sity (residents/ha) }\end{array}$ & 0.6392 & 128.60 & 0.00 & -97.53 & 29.09 & 250 \\
\hline $\begin{array}{c}\text { Change in distance to } \\
\text { center (kilometers) }\end{array}$ & -0.712 & 8.729 & 0.00 & -107.275 & 7.304 & 250 \\
\hline $\begin{array}{c}\text { Change in jobs: pop } \\
\text { ratio }\end{array}$ & 0.350 & 11.74 & 0.00 & -11.65 & 2.33 & 250 \\
\hline $\begin{array}{c}\text { Change in distance to } \\
\text { work (kilometers) }\end{array}$ & -2.46 & 92.22 & 0.00 & -79.66 & 16.46 & 209 \\
\hline $\begin{array}{c}\text { Change in car } \\
\text { ownership (cars per } \\
\text { household) }\end{array}$ & -0.0639 & 1 & 0 & -3 & 0.64 & 266 \\
\hline
\end{tabular}

Table 2: Frequency table of continuous and count data.

Change was calculated as current value minus the previous value, with a negative value relating to a lower current level than than the previous level.

Additionally, a variable was created to reflect the current residential city of either Glasgow or Edinburgh. This variable was not found to be significant either as a main effects term or by interacting all other variables with it and was hence removed. The output shown in Table 4 presents the final ordinal regression model specification that was found to have the greatest explanatory power (pseudo R square values).

\begin{tabular}{|l|l|r|}
\hline \multicolumn{2}{|c|}{ Variable Name } & Response Categories \\
\hline $\begin{array}{l}\text { Change in accommoda- } \\
\text { tion type }\end{array}$ & No change & 74 \\
& From house to flat & 18 \\
& From flat to house & 8 \\
\hline Change in driving license & No change & 95 \\
status & Gained license & 5 \\
\hline Change in employment & No change & 84 \\
status & Currently working but not previously working & 9 \\
& Currently not working but previously working & 7.3 \\
\hline Change in income mea- & Less or a lot less & 20 \\
sured at the household level & No change & 21 \\
& More or a lot more & 58 \\
\hline Previous utban rural class & Large Urban Areas Pop> 125,000 & 85 \\
(all current locations are & Other Urban Areas Pop 10,000 to 125,000 & 8 \\
Large Urban areas) & Accessible Small Town Pop 3,000 to 10,000 & 2 \\
& Remote Small Town Pop 3,000 to 10,000 & 0 \\
& Accessible Rural & 2 \\
& Remote Rural & 1 \\
& Greater London & 2 \\
\hline
\end{tabular}

Table 3: Frequency table of categorical data.

\section{$6 \quad$ Results}

Of the urban form variables, the change in ward population density and previous urban rural classification had no statistically significant effect on change in distance driven, all else being equal. The change in distance to the urban center had a statistically significant effect ( $p$-value of 10 percent). An increase in distance to the nearest urban center of $2.059 \mathrm{~km}$ (the standard deviation of the change in distance to urban center for those who had moved home) was associated with a 0.177 increased ordered log odds of being in a higher category of change in car use (beta value multiplied by s.d.). That is, increased distance to the urban center was related to a slightly higher likelihood of reporting an increase in car use. The change in jobs to population ratio of the ward also had a statistically significant effect, with an increase in the number of jobs compared to the population being associated with a reduction in car use. Specifically, for every increase of 2.95 (standard deviation for movers) in the jobs to population ratio, there was an increased ordered $\log$ odds of 0.274 of being in a lower category of change in car use. That is, an increased number of jobs compared to the resident population was associated with reporting a reduction in car use.

Of the socio-demographic variables, the change in household income was statistically significant at the 10 percent level. Those with no change in household income had a statistically significant, 0.643 increased ordered log odds of being in a lower level of change in car use compared to households with an increased income. Change in work status was not statisti- 


\begin{tabular}{|c|c|c|c|c|}
\hline & & Sig. & 95\% Confidence & aterval \\
\hline & B & (p-value) & Lower Bound & Upper Bound \\
\hline Threshold & & & & \\
\hline Drive a lot less & -.992 & .347 & -3.061 & 1.077 \\
\hline Drive a little less & -.449 & .671 & -2.517 & 1.619 \\
\hline Drive about the same & 1.328 & .212 & -.757 & 3.413 \\
\hline Drive a little more & 2.286 & .034 & .171 & 4.401 \\
\hline Location & & & & \\
\hline Reduction in income & -.319 & .270 & -.886 & .248 \\
\hline No change in income & -.643 & $.019^{* *}$ & -1.180 & -.107 \\
\hline Increase in income & $0^{\mathrm{a}}$ & & & \\
\hline Age $16-24$ & -.747 & .126 & -1.705 & .211 \\
\hline Age $25-34$ & .044 & .894 & -.610 & .699 \\
\hline Age $35-44$ & -.230 & .510 & -.912 & .453 \\
\hline Age $45-54$ & -.696 & $.060^{*}$ & -1.421 & .029 \\
\hline Age $55-64$ & -.525 & .205 & -1.336 & .286 \\
\hline Age $65+$ & $0^{\mathrm{a}}$ & & & \\
\hline No change in work status & .609 & .306 & -.556 & 1.774 \\
\hline Gained employment & 1.143 & .108 & -.252 & 2.538 \\
\hline Lost employment & $0 \mathrm{a}$ & & & \\
\hline Gained driving license & 2.536 & $.000^{* * *}$ & 1.575 & 3.497 \\
\hline No change in license & $0^{a}$ & & & \\
\hline No change in accom type & -.265 & .439 & -.937 & .407 \\
\hline Change from house to flat & -.410 & .395 & -1.354 & .535 \\
\hline Change from flat to house & $0^{\mathrm{a}}$ & & & \\
\hline Change in distance to work & .013 & $.086^{*}$ & -.002 & .027 \\
\hline Change in ward density & -.002 & .581 & -.010 & .006 \\
\hline Change in distance to urban center & 0.086 & $.100^{*}$ & -0.016 & .188 \\
\hline Change in jobs:pop ratio & -.093 & $.073^{*}$ & -.194 & .009 \\
\hline Change in car ownership & .341 & $.081^{*}$ & -.042 & .723 \\
\hline Previously Large Urban area & -.213 & .763 & -1.596 & 1.170 \\
\hline Previously Other Urban area & -.793 & .388 & -2.595 & 1.009 \\
\hline Previously Accessible Small Town & 1.182 & .253 & -.843 & 3.207 \\
\hline Previously Accessible Rural & -.217 & .852 & -2.503 & 2.069 \\
\hline Previously Remote Rural & -.566 & 679 & -3.245 & 2.113 \\
\hline Previously Greater London & $0^{a}$ & & & \\
\hline $\mathrm{N}$ & 183 & & & \\
\hline - 2 Log-likelihood Intercept Only & 509.478 & & & \\
\hline - 2 Log-likelihood Final & 415.468 & & & \\
\hline Pseudo R Square (Cox and Snell) & .402 & & & \\
\hline Adjusted Pseudo R Square (McFadden) & .177 & & & \\
\hline
\end{tabular}

Table 4: Change in urban form and distance driven parameter estimates. 
cally significant. As expected, having gained a driving license was statistically significantly associated with a large increase in probability of having increased car use (ordered log odds of 2.536) compared to those who had no change in license status. No clear pattern emerges as to how age affects the change in car use. The change in distance traveled to the place of work was statistically significant; an increase of $16.45 \mathrm{~km}$ in the distance to the place of work (one standard deviation) was related to a 0.213 increase in the ordered log odds of having a higher level of change in car use. That is, increased distance to work was associated with an increase in car use, all else being equal.

Change in car ownership was statistically significant, with increased car ownership relating to an increase in car use. For every increase of one car, there was an increase of 0.341 ordered log odds of being in a higher category of change in car use.

Removal of "change in distance traveled to work" did not affect the coefficients of other explanatory variables, suggesting that change in distance to work is not collinear with change in urban form variables. That is, change in urban form is independent of change in distance to work.

\section{Discussion and conclusions}

While change in car use was explained to a large extent by change in car ownership, a number of urban form variables were also statistically significant predictors of change in car use for those who had moved home in the previous three years. For such households, increased distance to the nearest urban center and a reduction in the number of jobs in the ward compared to the population (a proxy for land-use mix) both related to a reported increase in car use; however, the magnitude of the effects was small compared to car ownership. Having one less car had the similar effect on reported change in car use as having three more jobs in the ward per person, or moving more than $4 \mathrm{~km}$ closer to a city center. These results are similar to those presented by Stead (2001), who found through cross-sectional analyses that socio-demographic variables, including car ownership, explained between 19 and 24 percent of distance traveled, while urban form explained only 3 percent. It may be the case, however, that urban form also influences car ownership, and thus the total impact (direct and indirect) of urban form on car use may be greater.

These findings give some support to Scottish Planning Policy, which suggests that by intensifying urban areas, average household distance driven can be reduced. It is important to recognize, though, that the result of changing the built form of urban areas in Scotland may not be comparable to the result of relocation to a different urban form in Scotland presented here, as a relocation creates an instantaneous change in urban form, whereas intensification, by its nature, is a more gradual process. However, if the effects were similar, very large changes to Scottish urban areas would be required to reduce car use by any significant magnitude. Also, it is important to recognize that while intensification might lead to a reduction in the average distance driven, intensification would also mean more people in a given area. Hence, unless the reduction was substantial, there would be a greater distance driven per unit area as a result of intensification, with the associated problems of congestion and poor air quality that intensification policies were supposed to reduce. The magnitude of any reduction in distance driven cannot be determined through the analysis presented in this paper, as it is self reported on a Likert scale; however, the percentage change in distance driven would need to be greater than the percentage change in population density for a reduction in distance driven per unit area. Echenique et al. (2012) estimated that a doubling of density would relate to a 10 percent reduction in vehicle miles traveled (VMT) for three case study areas in the southeast of England. Ewing and Cevero $(2001 ; 2010)$ found a 5 percent reduction in VMT as a result of doubling density in the U.S. Unless the magnitude of the effect of intensification was far greater in Glasgow and Edinburgh, intensification would therefore not reduce distances driven in the two cities. Although the average distance driven per person would be slightly less, this driving would be intensified into the city.

Urban forms may require longer time scales to be changed, and the effect on distance driven may be relatively small. Given the greater effect of car ownership on distance driven, policies aimed at reducing car ownership may encourage a more immediate and significant reduction in car use than can be achieved through intensification.

Moreover, whether such intensification can be brought about in urban Scotland remains unclear. The study population showed a general preference for low-density areas, with preference for lower-density neighborhoods being stronger for households that already live in suburban areas (Jenks and Jones 2010). Clearly, policy aimed at intensifying Glasgow and Edinburgh needs to consider such residential preferences. Given the choice, it appears most people would choose suburban living; however, the choices available to householders are constrained by household resources and by property markets. It is possible that over longer periods of time, policy could manipulate the choice set available to householders by limiting the construction of more suburban forms and encouraging more compact urban development, thus pushing suburban lifestyles out of the economic reach of more households, despite their preference for suburban living.

Glasgow has experienced a dramatic loss of population 
over the last four decades, although the population has more recently stabilized and is predicted to increase by a relatively modest 1.4 percent by 2033 compared to 2008 levels, whereas Edinburgh is predicted to have 16.8 percent more residents in 2033 than in 2008 (General Register Office for Scotland 2010). In cities with a lack of housing supply and high housing costs, it is likely that new high-density developments would be economically viable, as the alternatives available to households with a particular budget is more limited. In cities that have suffered dramatic population loss, with vacant high-density housing such as Glasgow, it is questionable whether intensification is achievable against a backdrop of preferences for suburban living and a relatively affordable stock of such housing. As such, this research calls into question the effectiveness of intensification as a policy tool to reduce car use in urban Scotland.

\section{Acknowledgements}

This paper was conducted as part of the CityForm consortium (http://www.city-form.org/uk/index.html) funded by the Engineering and Physical Sciences Research Council (EPSRC) under its Sustainable Urban Environments Programme (Grant number GR/520529/01). The consortium comprised a multidisciplinary team based at the universities of de Montford, Heriot-Watt, Oxford Brookes, Sheffield, and Strathclyde. The consortium was supported by the following non-academic partners: Corus, the Environment Agency, Glasgow City Council, Groundwork UK, The Landscape Institute, Leicester City Council, Oxford City Council, The Prince's Foundation, Rogers Stirk Harbour + Partners, Scottish Executive, Sheffield City Council, Sheffield Wildlife Trust, Strathclyde Passenger Transport, and URBED.

\section{References}

Aditjandra, P. T., X. J. Cao, and C. Mulley. 2012. Understanding neighbourhood design impact on travel behaviour: An application of structural equations model to a British metropolitan data. Transportation Research Part A: Policy and Practice 46(1): 22-32. http://dx.doi.org/10.1016/j. tra.2011.09.001.

Banister, D., S. Watson, and C. Wood 1997. Sustainable cities: Transport, energy, and urban form. Environment and Planning B 24: 125-144. http://dx.doi.org/10.1068/b240125.

Bhat, C., and H. Zhao. 2002. The spatial analysis of activity stop generation. Transportation Research Part B: Methodological 36(6): 557-575. http://dx.doi.org/10.1016/ S0191-2615(01)00019-4.

Boarnet, M. G., and S. Sarmiento. 1998. Can land-use policy really affect travel behaviour? A study of the link between non-work travel and land-use characteristics. Urban Studies 35(7): 1155-1169. http://dx.doi. org/10.1080/0042098984538.

Breheny, M. 1997. Urban compaction: Feasible and acceptable? Cities 14(4): 209-217. http://dx.doi.org/10.1016/ S0264-2751(97)00005-X.

Cervero, R. (2002). Built environments and mode choice: Toward a normative framework. Transportation Research Part D: Transport and Environment 7(4): 265-284. http:// dx.doi.org/10.1016/S1361-9209(01)00024-4.

Cervero, R. and J. Day. 2008. Suburbanization and transit oriented development in China. Transport Policy 15(2): 315-323. http://dx.doi.org/10.1016/j.tranpol.2008.12.011.

Cervero, R., K. Kockelman. 1997. Travel demand and the 3Ds: Density, diversity, and design. Transportation Research Part D: Transport and Environment 2(3): 199-219. http:// dx.doi.org/10.1016/S1361-9209(97)00009-6.

Dieleman, F. M., M. Dijst, M., and G. Burghouwt. 2002. Urban form and travel behaviour: micro-level household attributes and residential context. Urban Studies 39(3): 507527. http://dx.doi.org/10.1080/00420980220112801.

Dillman, D. A. 2007. Mail and Internet Surveys: The Tailored Design Method. New York: John Wiley \& Sons.

Echenique, M. H., A. J. Hargreaves, G. Mitchell, and A. Namdeo. 2012. Growing cities sustainably. Journal of the American Planning Association 78(2): 121-137. http:// dx.doi.org/10.1080/01944363.2012.666731.

Ewing, R., R. Pendall, and D. Chen. 2003. Measuring sprawl and its transportation impacts. Transportation Research Record: Journal of the Transportation Research Board 1831: 175-183. http://dx.doi.org/10.3141/1831-20. 
Ewing, R., and R. Cervero. 2001. Travel and the built environment: A synthesis. Transportation Research Record: Journal of the Transportation Research Board 1780: 87-114. http:// dx.doi.org/10.3141/1780-10.

Ewing, R., and R. Cervero. 2010. Travel and the built environment-A meta-analysis. Journal of the American Planning Association 76(3): 265-294. http://dx.doi. org/10.1080/01944361003766766.

Frey, H., N. S. Ferguson, S. G. Bagaeen, and L. Woods. 2005. Suburbs reconsidered: Form, mobility and sustainability. Built Environment 32(3): 250-266. http://dx.doi. org/10.2148/benv.32.3.250.

General Register Office for Scotland. 2001. 2001 Census Data. Edinburgh: Scotland.

General Register Office for Scotland. 2010. Population Estimates Time Series Data. Retrieved from http://www. gro-scotland.gov.uk/statistics/publications-and-data/ population-estimates/mid-year/population-estimates-timeseries-data.html

Gordon, P. and H. Richardson. 1989. Gasoline consumption and cities - a reply. Journal of the American Planning Association 55: 342-346.

Handy, S. 2005. Critical assessment of the literature on the relationships among transportation, land use, and physical activity. Department of Environmental Science and Policy, University of California, Davis. Prepared for the Committee on Physical Activity, Health, Transportation, and Land Use. Washington: Transportation Research Board.

Handy, S., X. Cao, and P. Mokhtarian. 2005. Correlation or causality between the built environment and travel behaviour? Evidence from Northern California. Transportation Research Part D 10(6): 427-444. http://dx.doi. org/10.1016/j.trd.2005.05.002.

Hull, A. 2008. Policy integration: What will it take to achieve more sustainable transport solutions in cities?. Transport Policy 15(2): 94-103. http://dx.doi.org/10.1016/j.tranpol.2007.10.004

Jenks, M., and C. Jones (Eds.). 2009. Dimensions of the Sustainable City (vol. 2). London: Springer. http://dx.doi. org/10.1007/978-1-4020-8647-2

Khattak, A. J., and D. Rodriguez. 2005. Travel behaviour in neo-traditional neighbourhood developments: A case study in USA. Transportation Research Part A: Policy and Practice: 39(6): 481-500.

Kitamura, R., P.L. Mokhtarian, and L. Laidet. 1997. A microanalysis of land use and travel in five neighborhoods in the San Francisco Bay Area. Transportation 24(2): 125-158. http://dx.doi.org/10.1023/A:1017959825565.

Krizek, K. (2003). Residential relocation and changes in urban travel: Does neighborhood-scale urban form matter? Journal of the American Planning Association 69(3): 265-281. http://dx.doi.org/10.1080/01944360308978019.

Næss, P. (2005). Residential location affects travel behaviourbut how and why? The case of Copenhagen metropolitan area. Progress in Planning 63(2): 167-257. http://dx.doi. org/10.1016/j.progress.2004.07.004.

National Planning Framework for Scotland. 2004. Edinburgh: Scottish government.

Newman, P., and J. Kenworthy. 1989. Cities and automobile dependency. Aldershot, UK: Gower.

Ordnance survey. 2008. Address point data. Retrieved from http://www.ordnancesurvey.co.uk.

Scottish Government. 2004. Scottish Executive Urban Rural Classification 2003-2004. Retrieved from http://www.scotland.gov.uk/Publications/2004/06/19498/38797.

Scottish Government. 2010. Scottish Planning Policy. Retrieved from http://www.scotland.gov.uk/Publications /2010/02/03132605/0.

Senior, M. L., C. J. Webster, and N. E. Blank. 2004. Residential preferences versus sustainable cities: Quantitative and qualitative evidence from a survey of relocating owneroccupiers. Town Planning Review 75(3): 337-357. http:// dx.doi.org/10.3828/tpr.75.3.5.

Snellen, D., A. Borgers, and H. Timmermans. 2002. Urban form, road network type, and mode choice for frequently conducted activities: A multilevel analysis using quasi-experimental design data. Environment and Planning A 34(7): 1207-1220. http://dx.doi.org/10.1068/a349.

Souche, S. 2010. Measuring the structural determinants of urban travel demand. Transport Policy 17(3): 127-134. http://dx.doi.org/10.1016/j.tranpol.2009.12.003.

Stead, D. 2001. Relationships between land use, socioeconomic factors, and travel patterns in Britain. Environment and Planning B 28(4): 499-528. http://dx.doi.org/10.1068/ b2677.

Stead, D., and E. Hoppenbrouwer. 2004. Promoting an urban renaissance in England and the Netherlands. Cities 21(2): 119-136. http://dx.doi.org/10.1016/j.cities.2004.01.005.

$\mathrm{Su}$, Q. 2010. Travel demand in the US urban areas: A system dynamic panel data approach. Transportation Research Part A: Policy and Practice 44(2): 110-117.

Timmermans, H., P. van der Waerden, M. Alves, J. Polak, S. Ellis, A. S. Harvey, and R. Zandee. 2003. Spatial context and the complexity of daily travel patterns: An international comparison. Journal of Transport Geography 11(1): 3746. http://dx.doi.org/10.1016/S0966-6923(02)00050-9.

Vandermissen, M. H., P. Villeneuve, M. Theriault. 2003. Analyzing changes in urban form and commuting time. The 
Professional Geographer 55(4): 446-463. http://dx.doi. org/10.1111/0033-0124.5504004.

Wall, W. D., and H. L. Williams. 1970. Longitudinal Studies and the Social Sciences. London: Heinemann.

Williams, K. 1997. The effectiveness of the UK planning system in delivering sustainable development via urban intensification. Unpublished Ph.D. thesis, Oxford Brookes University.

Williams, K. 1999. Urban intensification policies in England: Problems and contradictions. Land Use Policy 16(3): 167178. http://dx.doi.org/10.1016/S0264-8377(99)00010-1.

Williams, K. 2004. Can urban intensification contribute to sustainable cities? An international perspective. City Matters: Official Electronic Journal of Urbanicity.

Xing, Y., S.L Handy, and P. L. Mokhtarian. 2010. Factors associated with proportions and miles of bicycling for transportation and recreation in six small US cities. Transportation Research Part D: Transport and Environment 15(2): 73-81. http://dx.doi.org/10.1016/j.trd.2009.09.004. 